\title{
Hemoglobin Bethesda Causing Polycythemia in a Japanese Family
}

\author{
Issei Kawashima, Koichiro Arima, Tetsuya Hanada, Teruo Harano*, Keiichi Harada, \\ Yasuo MATSUOKA and Shoichiro IRIMAJIRI
}

\begin{abstract}
A family with Hemoglobin Bethesda is reported. A 23-year-old man was hospitalized for the evaluation of polycythemia. Analysis of hemoglobin using high pressure liquid chromatography showed the presence of hemoglobinopathy. Separation of globin into $\alpha$ and $B$ chains revealed approximately $50 \%$ of the $B$ chain to be abnormal. Analysis of the DNA sequence of the $B$ chain gene identified $\mathrm{Hb}$ Bethesda. The family study disclosed that his father and sister also had the same hemoglobinopathy. This case is the first report of $\mathrm{Hb}$ Bethesda in Japan.

(Internal Medicine 33: 242-247, 1994)
\end{abstract}

Key words: polycythemia, hemoglobinopathy

\section{Introduction}

Hemoglobin Bethesda is a variant of hemoglobin which presents with polycythemia. Although there are several reports on this type of variant with development of polycythemia (1), no case of $\mathrm{Hb}$ Bethesda in Japan has been.

Here, we present the first documented case of $\mathrm{Hb}$ Bethesda in Japan, and the results of amino acid analysis, DNA sequencing analysis, and the hemoglobin oxygen equilibrium curve.

\section{Case Report}

In 1993, a 23-year-old man visited our hospital for evaluation of general fatigue. He was hospitalized for analysis of abnormal results in liver function tests and erythrocytosis. Physical findings on admission revealed no abnormality. The results of diagnostic blood tests performed at the time of admission are presented in Table 1 . In evaluation of the increased red cell count, the circulating blood volume as measured by sodium chromates (2), was found to be increased. These findings established the diagnosis of polycythemia. Serum erythropoietin level and arterial blood gas analysis were within normal limits. Neutrophil alkaline phosphatase score, serum vitamin $\mathrm{B}_{12}$, total iron binding capacity and serum iron were also normal. However, an elevated value of $4.18 \mu \mathrm{mol} / \mathrm{ml} \mathrm{RBC}$ was measured for 2,3-diphosphoglyceric acid (2,3-DPG) (3). This patient had a normal myelogram. His serum was positive $\mathrm{HBs}$ and for $\mathrm{HBe}$ antigen.
Table 1. Laboratory Values on Admission

\begin{tabular}{|c|c|}
\hline \multicolumn{2}{|l|}{ Hematology } \\
\hline $\mathrm{RBC}$ & $607 \times 10^{4} / \mathrm{mm}^{3}$ \\
\hline $\mathrm{Hb}$ & $19.1 \mathrm{~g} / \mathrm{dl}$ \\
\hline Het & $57.7 \%$ \\
\hline WBC & $3,800 / \mathrm{mm}^{3}$ \\
\hline N. band & $4 \%$ \\
\hline N. segment & $52 \%$ \\
\hline Mono & $3 \%$ \\
\hline Lymph & $41 \%$ \\
\hline Retic & $15 \%$ \\
\hline PLTs & $6.7 \times 10^{4} / \mathrm{mm}^{3}$ \\
\hline \multicolumn{2}{|l|}{ Coagulation } \\
\hline Prothrombin time & $72 \%$ \\
\hline APTT & $32.7 \mathrm{sec}(30.4 \mathrm{sec})$ \\
\hline Fibrinogen & $150 \mathrm{mg} / \mathrm{dl}$ \\
\hline \multicolumn{2}{|l|}{ Circulating blood volume } \\
\hline Red cell volume & $3,381 \mathrm{ml}(1,616 \pm 307 \mathrm{ml})$ \\
\hline Total blood volume & $5,507 \mathrm{ml}(3,725 \pm 596 \mathrm{ml})$ \\
\hline Total plasma volume & $2,126 \mathrm{ml}(2,104 \pm 400 \mathrm{ml})$ \\
\hline Erythropoietin & $21.7 \mathrm{mIU} / \mathrm{ml}(9-40 \mathrm{mIU} / \mathrm{ml})$ \\
\hline 2,3-DPG & $4.18 \mu \mathrm{mol} / \mathrm{ml}(1.8-2.2 \mu \mathrm{mol} / \mathrm{ml} \mathrm{RBC})$ \\
\hline Vitamin $B_{12}$ & $551 \mu \mathrm{g} / \mathrm{dl}(210-840 \mu \mathrm{g} / \mathrm{dl})$ \\
\hline Serum ion & $183 \mu \mathrm{g} / \mathrm{dl}(60-180 \mu \mathrm{g} / \mathrm{dl})$ \\
\hline $\begin{array}{l}\text { Bone marrow biopsy } \\
\text { normocellular }\end{array}$ & \\
\hline
\end{tabular}

From the Department of Internal Medicine, Kawasaki Municipal Hospital, Kawasaki and *the Department of Biochemistry, Kawasaki Medical School, Kurashiki Received for publication September 13, 1993; Accepted for publication February 17, 1994

Reprint requests should be addressed to Dr. Issei Kawashima, the Department of Internal Medicine, Kawasaki Municipal Hospital, 12-1, Shinkawa, Kawasakiku, Kanagawa 210 


\section{Methods and Results}

Cation exchange high pressure liquid chromatography (HPLC) of hemoglobin fraction

HPLC (Fig. 1) revealed an abnormal variant peak (abn.Hb), which emerged after $\mathrm{HbA}$ and $\mathrm{HbA}_{2}$ using cation exchange HPLC (Micropeal BPG-17, 7.5 $\times 150 \mathrm{~mm}$ column). Absorbance $(415 \mathrm{~nm})$ was measured to determine the elutes of the individual hemoglobin bands (4).

\section{Hemoglobin fractionation by isoelectric electrophoresis}

Using a polyacrylamide gel plate (1), isoelectric electrophoresis resolved two major components, $\mathrm{HbA}$ and abn.Hb (Fig. 2), which were demonstrated as abnormal slow-moving bands.

Separation of hemoglobin $\alpha$-chain and $\beta$-chain by carboxylmethyl (CM) cellulose column

Hemoglobin was biosynthesized with incorporation of tritium-labeled leucine (5), and then subjected to uread CMcellulose column chromatography. The abnormal $\beta$ peak was eluted after the peak of the normal $\beta$ chain (Fig. 3).

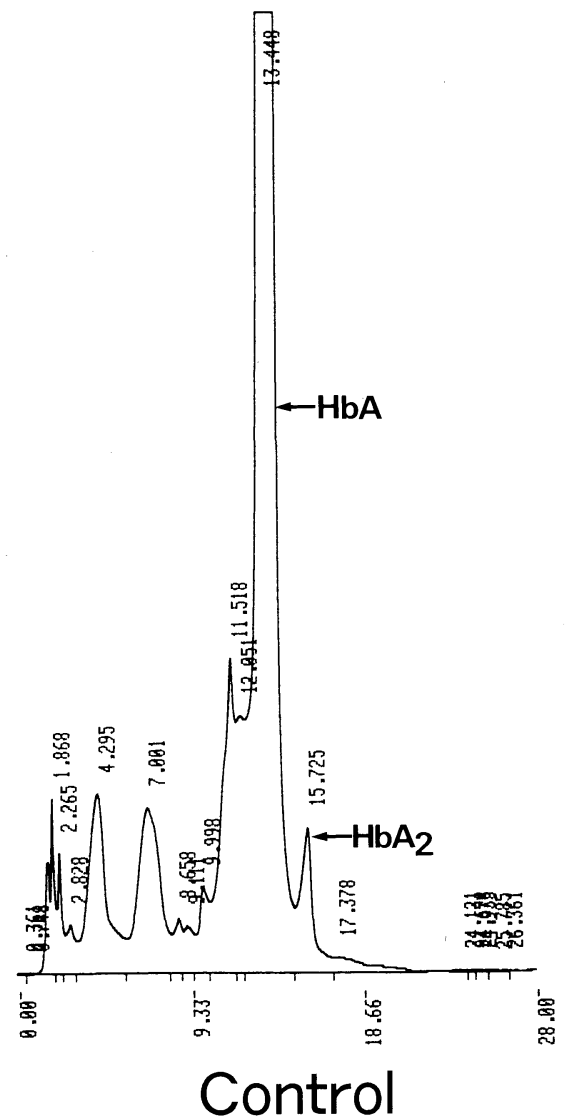

Isolation of the abnormal hemoglobin peptide

The $B$ chain was aminoethylated, digested with trypsin, and the obtained peptide fragments were separated by reversed phase on HPLC (SG120 column, 4.6×250 mm) (6) (Fig. 4). The peak for the $B$ T-15 peptide was absent, but no abnormal peak was observed. Amino acid analysis of each peak disclosed that ß T-15 had emerged with $\beta$ T- $6,7,8$ peptide (Table 2), and that histidine had been substituted for tyrosine in the $B \mathrm{~T}-15$ (Table 2). This substitution, B145 Tyr $\rightarrow$ His, has already been reported in $\mathrm{Hb}$ Bethesda.

Analysis of the DNA sequence in $\beta$-chain globulin gene

To further clarify the results of the amino acid analysis, DNA sequencing was done. The nucleotide sequence in the B-chain globulin gene was analyzed using DNA obtained from the patient's peripheral blood (7). Two amplification primer sets were used for the PCR method (8). The amplification of DNA was carried out by the dideoxy method for sequencing. $B$ Bethesda and $B$ normal clone were obtained. Then the reaction samples were analyzed by electrophoresis on a polyacrylamide gel.

Both $\mathrm{T}$ and $\mathrm{C}$ were observed for the first base of the $B 145$ codon, indicating that the patient globulin was a heterozygote

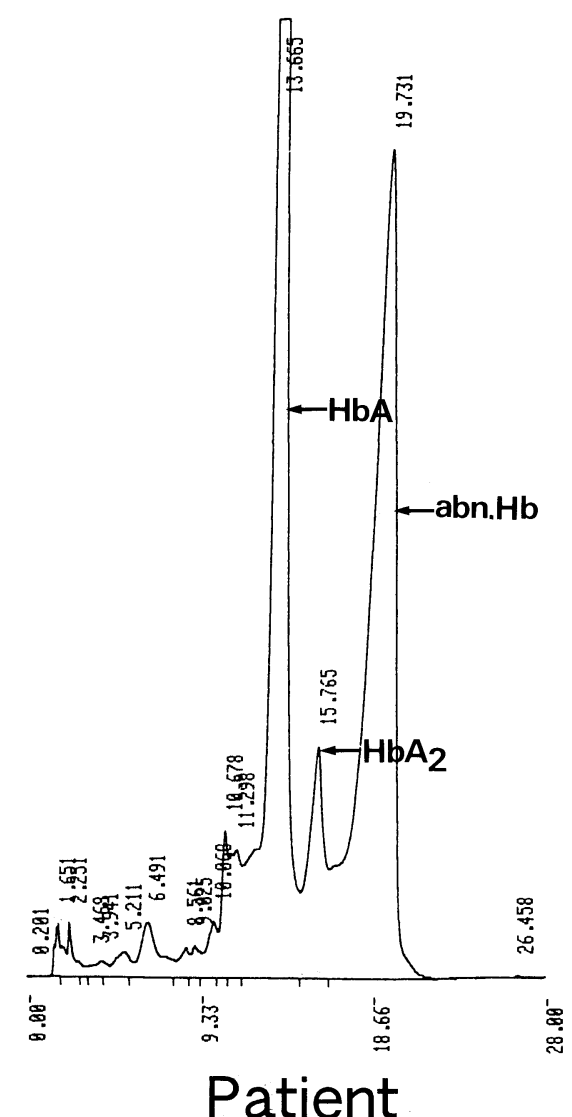

Fig. 1. Cation exchange HPLC of hemolysate. An abnormal $\mathrm{Hb}$ (abn.Hb) was eluted after $\mathrm{HbA}$ and $\mathrm{HbA}_{2}$. 


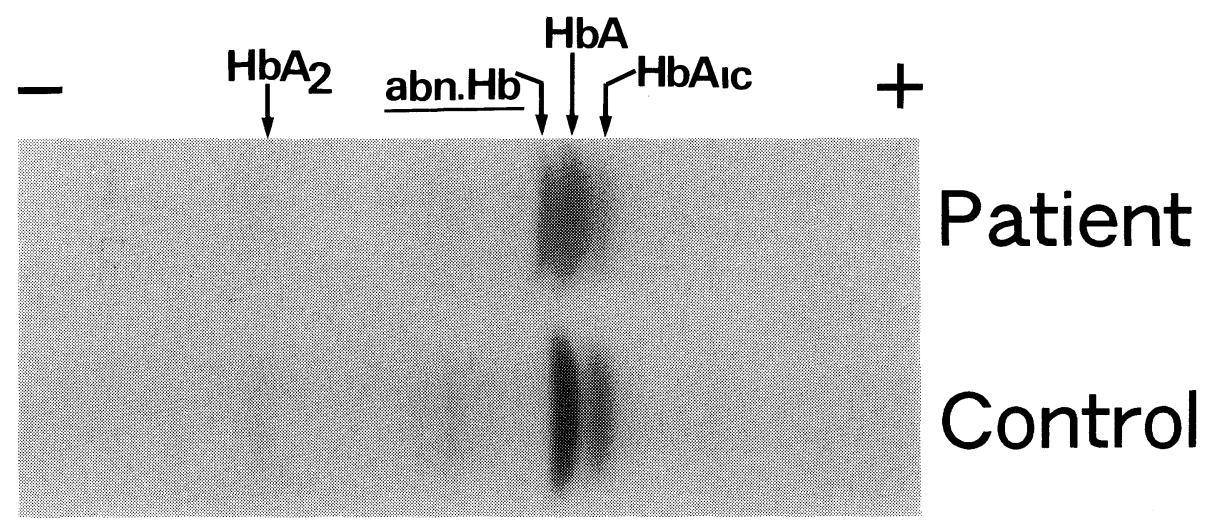

Fig. 2. Isoelectrofocusing of hemolysates on a polyacrylamide gel plate.

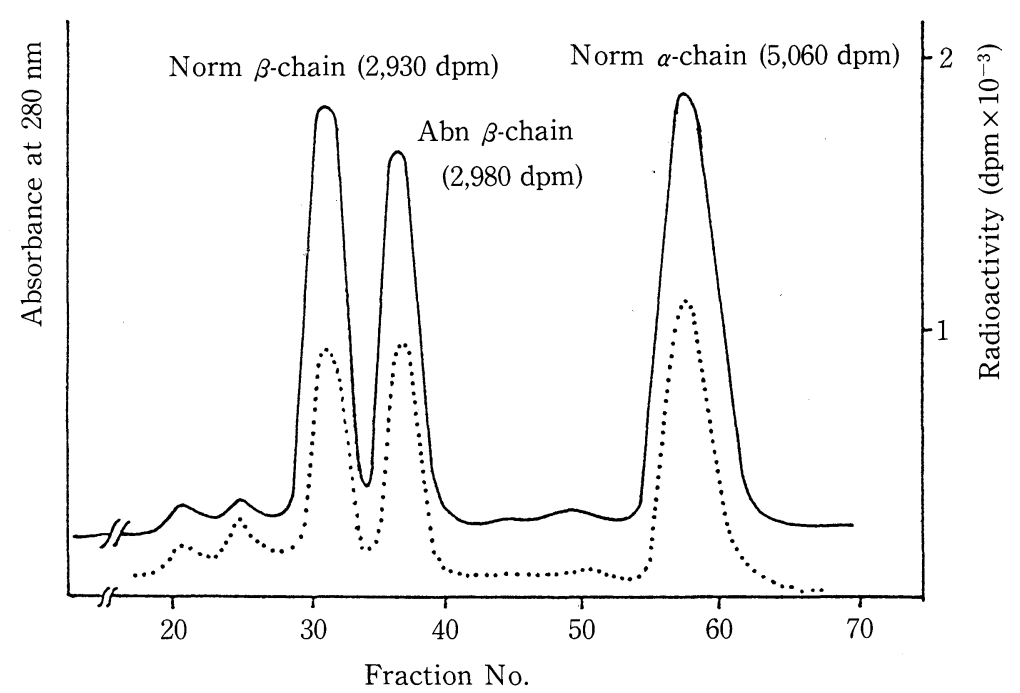

Fig. 3. Urea CM-cellulose column chromatography of the ${ }^{3} \mathrm{H}$-leucine-labeled globin. - absorbance, -----: radioactivity.

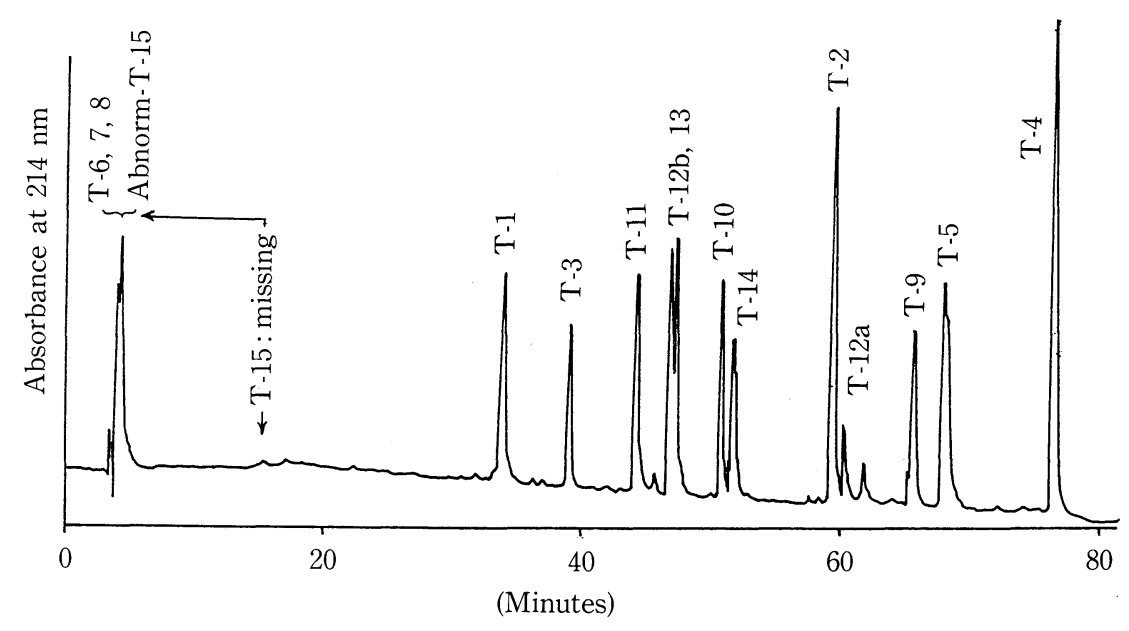

Fig. 4. Separation of the tryptic digest of the aminoacetylated B-Bethesda chain by HPLC on a Capcell Pak $5 \mathrm{C}_{18}$ SG120 column $(4.6 \mathrm{~mm}$ I.D. $\times 250 \mathrm{~mm}$ ) with a linear gradient of acetonitrile (from 0 to $50 \%$ ) in $9 \mathrm{mM}$ trimethylamine-acetic acid buffer (pH 6.0) at a flow rate of $0.7 \mathrm{ml} / \mathrm{min}$ for 100 minutes. 
Table 2. Amino Acid Composition of a Peptides Mixture Containing the Abnormal ß T-15

\begin{tabular}{lccccc}
\hline \multirow{2}{*}{ Amino acid } & \multirow{2}{*}{$\begin{array}{c}\text { Found } \\
\text { (nmol) }\end{array}$} & \multicolumn{4}{c}{ Theoretical molecular ratio } \\
\cline { 3 - 6 } & T-6 & T-7 & T-8 & T-15 \\
\hline Glycine & 7.33 & & 1 & & \\
Alanine & 7.93 & & 1 & & \\
Valine & 6.18 & 1 & & & \\
Tyrosine & 0.00 & & & & 1 \\
Lysine & 16.85 & 1 & 1 & 1 & \\
Histidine & 19.91 & & 1 & & 1 \\
\hline
\end{tabular}

of $\mathrm{Hb}$ Bethesda. Furthermore, clones of the $\mathrm{B}$ globin genes were separated, and the results assigned either TAT (tyrosine) or CAT (histidine) for codon 145 (Fig. 5).

\section{The oxygen equilibrium curve}

The oxygen equilibrium curves were measured on whole blood that had been diluted 150 times with isotonic phosphate buffer solution $\left(0.15 \mathrm{M} \mathrm{K}_{2} \mathrm{HPO}_{4}+0.15 \mathrm{M} \mathrm{NaH}_{2} \mathrm{PO}_{4}\right)$, $\mathrm{pH}$ of 6.9 or 7.45 , at $37^{\circ} \mathrm{C}$. The final concentration of hemoglobin was adjusted to $60 \mu \mathrm{M}$ on hemo basis (9).
The oxygen equilibrium curves of the patient's red cell suspension did not show the typical sigmoid shape especially at low $\mathrm{O}_{2}$ saturation (Fig. 6).

Comparison of the $\mathrm{P}_{50}$ values indicated that the $\mathrm{Hb}$ Bethesda red blood cells had an oxygen affinity 2.7 to 2.9 times greater than the normal red blood cells. The low saturation region of the oxygen equilibrium curve for this patient's red blood cells showed the loss of cooperative intersubunit interaction.

\section{Family study}

The data on this family are presented in Table 3 . His father and his younger sister carried the same abnormal hemoglobin and had similar polycythemia.

\section{Discussion}

There have been six previously reported cases of $\mathrm{Hb}$ Bethesda [B145(HC2)Tyr $\rightarrow$ His], including North European Caucasians $(5,10,11)$, a French Canadian (12), and a Chinese living in America (13). This is the first report of $\mathrm{Hb}$ Bethesda in Japan. All Hb Bethesda patients had secondary polycythemia because of inefficient $\mathrm{O}_{2}$ dissociation from the abnormal hemoglobin.

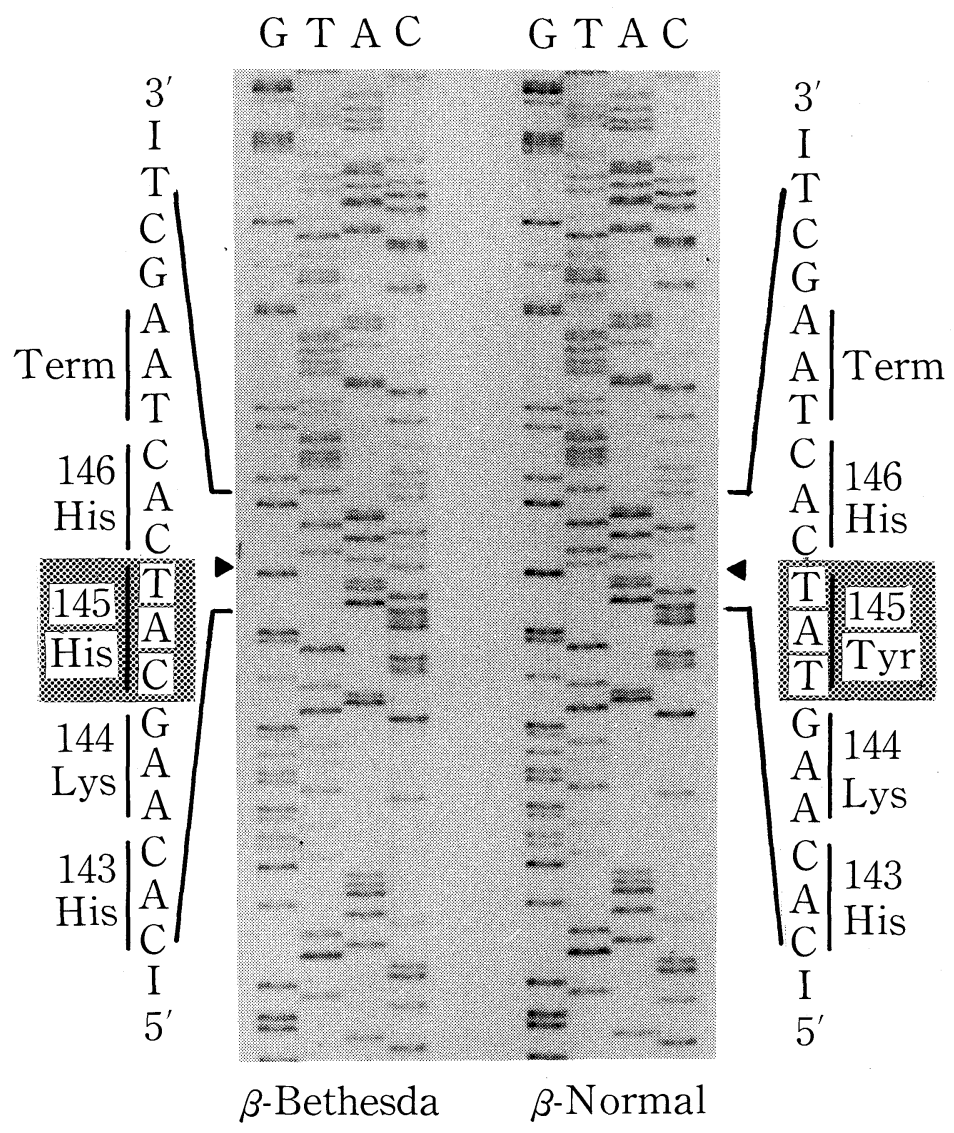

Fig. 5. DNA sequence of $\beta$-Bethesda gene. $B 145$ codon was changed from TAT (tyrosine) to CAT (histidine). 


\section{KAWASHIMA et al}

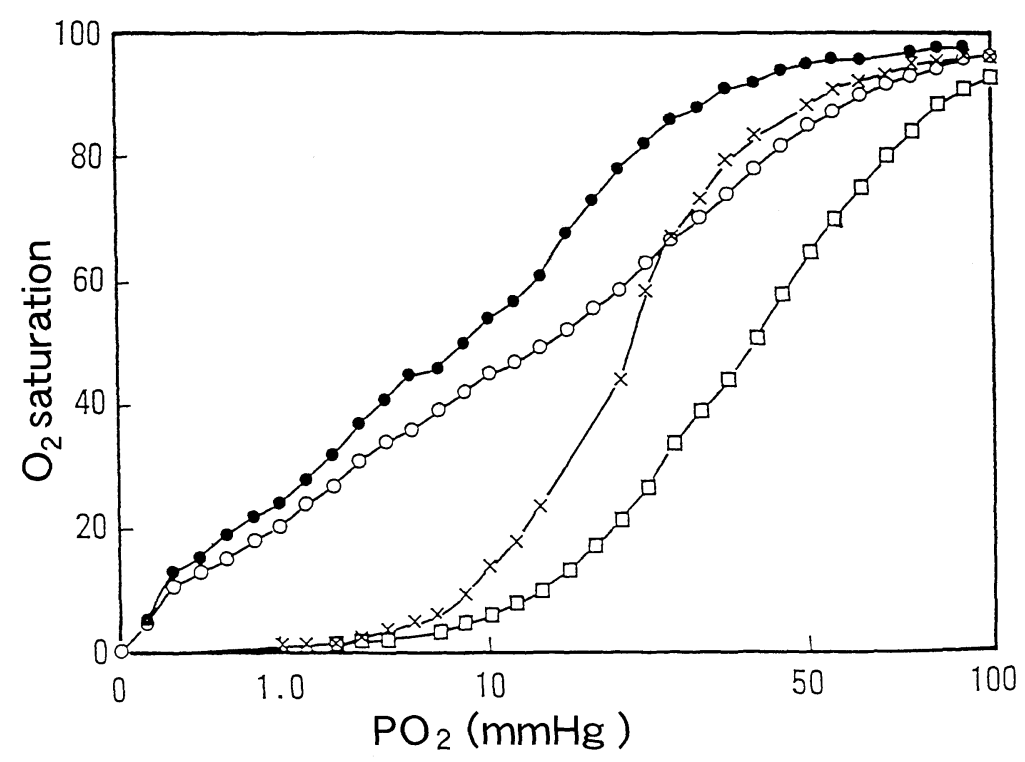

Fig. 6. Oxygen equilibrium curves of erythrocytes from a heterozygote of $\mathrm{Hb}$ Bethesda (Beth./A) and a normal control (A/A). The curves were obtained using the automated method of Imai et al (9). - - - Beth./A (pH 7.45), - O -: Beth./A (pH 6.9), - - : A/A (pH 7.45), $-\square-: \mathrm{A} / \mathrm{A}(\mathrm{pH} 6.9)$.

Table 3. Hematologic Findings of the Family

\begin{tabular}{lccc}
\hline & Proband & Father & Sister \\
\hline $\mathrm{RBC} \times 10^{4} / \mathrm{mm}^{3}$ & 607 & 653 & 675 \\
$\mathrm{Hb} \mathrm{g} / \mathrm{dl}$ & 19.1 & 19.1 & 14.1 \\
$\mathrm{Hct} \%$ & 53.6 & 53.6 & 45.6 \\
$\mathrm{HbF}(0.1-1.2 \%)$ & 0.32 & 0.22 & 0.15 \\
$\mathrm{HbA}(2.2-3.2 \%)$ & 2.86 & 2.28 & 2.07 \\
$\mathrm{Abnormal} \mathrm{Hb}(\%)$ & 49.5 & 48.6 & 48.3 \\
\hline
\end{tabular}

Oxygen equilibrium curve of the carriers is shifted to the left and the normal sigmoid curve was replaced by a straight line at the low saturation region.

An elevated value for 2,3-DPG was observed in our patient in contrast to previous reports of a normal level $(10,12,13) .2,3-$ DPG facilitates dissociation of oxygen from hemoglobin which results in improved oxygenation of the tissues (14).

The neutrophil alkaline phosphatase score, serum vitamin $\mathrm{B}_{12}$ and erythropoietin levels were consistent with previously reported cases of $\mathrm{Hb}$ Bethesda by Schmidt (12) and Bunn (13).

The only clinical manifestation in $\mathrm{Hb}$ Bethesda is persistent cutaneous flush due to the polycythemia. Cardiac and cerebrovascular complications have not been reported, and fetal oxygenation seemed undisturbed in a mother with $\mathrm{Hb}$ Bethesda (15). In this case, only the proband was found to have cutaneous flush.

Acknowledgments: Authors appreciate Dr. Kiyohiro Imai, Department of Physiology, Osaka University, School of Medicine, for his technical assistance of oxygen saturation curve.

\section{References}

1) MoriH. Relation between polycythemia and function of hemoglobin with amino acid substitution in a1 $\beta 2$ contact, Hb Chesapeake [ $\alpha 92$ (FG4) $\mathrm{Arg} \rightarrow$ Leu] and $\mathrm{Hb}$ J Cape Town [ $\alpha 92(\mathrm{FG} 4) \mathrm{Arg} \rightarrow$ GIn]. Kawasaki Med J 11: 41, 1985.

2) Read RC. Studies of red-cell volume and turnover using radiochromium. N Engl J Med 250: 1021, 1954.

3) Ericton A, Verdier CHD. A modified method for the determination of 2,3diphosphoglycerate in erythrocytes. Scand J Clin Lab Invest 29: 85, 1972.

4) Trivelli LA, Ranny HM, Lai HT. Hemoglobin components in the patient with diabetes mellitus. N Engl J Med 284: 353, 1971.

5) Hayashi A, Stamatoyannopoulos G, Yoshida A, Adamson J. Hemoglobin Rainier B145(HC2) Tyrosine $\rightarrow$ Cysteine and Hemoglobin Bethesda: B145(HC2) Tyrosine $\rightarrow$ Histidine. Nature New Biol 230: 264, 1971.

6) Sakai $T$. Determination of erythrocyte porphyrins by reversed phase high performance liquid chromatography using capsule type silica gels coated with silicone polymer. J Chromatography 433: 73, 1989.

7) Poncz M, Solowiejezyk D, Harpel B, Mory Y, et al. Construction of human gene libraries from small amounts of peripheral blood: Analysis of ß-like globin genes. Hemoglobin 6: 27, 1982.

8) Harano T, Harano K, Ueda S. Application of polymerase chain reaction (PCR) to molecular analysis of the $B$ globin gene of Japanese $B^{\circ}$ Thalassemia-Hb San Diego [B109(G11) Val $\rightarrow$ Met]. Acta Hematol Jpn 53: $882,1990$.

9) Imai K, Morimoto H, Jotani M, Watari H, Hitota W, Kuroda M. Studies on the function of abnormal hemoglobin. I. An improved method for automatic measurement of oxygen equilibrium curve of hemoglobin. Biochim Biophys Acta 200: 189, 1970.

10) Adamson JW, Hayashi A, Stamatoyannopoulos G, Burger WF. Erythrocyte function and marrow regulation in Hemoglobin Bethesda ( $B 145$ Histidine). J Clin Invest 51: 2883, 1972.

11) Olsen JS, Gibson QH. The functional properties of Hemoglobin Bethesda. J Biol Chem 247: 3662, 1972.

12) Schmidt RM, Jue DL, Ali MM, Lyonnais J, Moo-Penn WF. Hemoglobin Bethesda, B145(HC2)Tyr $\rightarrow$ His, in a Canadian family. A J C P 66: 449, 1976. 


\section{A Family with Hemoglobin Bethesda}

13) Bunn HF, Bradley TB, Davis WE, et al. Structural and functional studies on Hemoglobin Bethesda $\left(\alpha 2 \beta 2^{145 H i s}\right)$, a variant associated with compensatory erythrocytosis. J Clin Invest 51: 2299, 1972.

14) Chanutin A, Curnish RR. Effect of organic and inorganic phosphates on the oxygen equilibrium of human erythrocytes. Arch Biochem Biophys 121: 96, 1967.

15) Charache $S$, Catalano $P$, Burns $S$, et al. Pregnancy in carriers of high affinity hemoglobins. Blood 65: 713, 1985. 